\title{
Dinuclear Silver(I) and Copper(II) Complexes of Hexadentate Macrocyclic Ligands Containing p-Xylyl Spacers
}

\author{
Christine J. McKènzie, ${ }^{a, *}$ Lars Preuss Nielsen $^{a}$ and Inger Søtofte ${ }^{b}$ \\ ${ }^{a}$ Department of Chemistry, Odense University, DK-5230 Odense M, Denmark and ${ }^{b}$ Department of Chemistry, \\ Technical University of Denmark, DK-2800 Lyngby, Denmark
}

\begin{abstract}
McKenzie, C. J., Nielsen, L. P. and Søtofte, I., 1998. Dinuclear Silver(I) and Copper(II) Complexes of Hexadentate Macrocyclic Ligands Containing $p$-Xylyl Spacers. - Acta Chem. Scand. 52: 571-577. (C) Acta Chemica Scandinavica 1998.

The cyclocondensation of terephthalic aldehyde with $N, N$-bis(3-aminopropyl)methylamine in the presence of silver(I) gives the dinuclear tetraimine Schiff base macrocyclic complex, $\left[\mathrm{Ag}_{2} \mathrm{~L}^{1}\right]\left(\mathrm{NO}_{3}\right)_{2} \quad\left(\mathrm{~L}^{1}=7,22-N, N^{\prime}\right.$-dimethyl$3,7,11,18,22,26$-hexaazatricyclo[ $\left.26.2 .2^{1.18} \cdot 2^{13.16}\right]$-tetratricosa-2, 11, 13, 15, 17, 26,$28,30,31,33$-decaene). $\left[\mathrm{Ag}_{2} \mathrm{~L}^{1}\right]\left(\mathrm{NO}_{3}\right)_{2}$ crystallizes in the monoclinic space group $P 2_{1} / c$, with $a=14.153(6), b=12.263(4), c=9.220(2) \AA, \beta=97.52(3) \AA$ and $Z=$ 2. The silver ions are strongly coordinated at each end of the macrocycle by the two imine nitrogen atoms [2.177(3) and 2.182(3) $\AA$ ] with close interatomic interactions to an oxygen atom of a nitrate ion and an amine nitrogen atom [2.580(2) and 2.690(2) $\AA$ ]. The $\mathrm{Ag} \cdots \mathrm{Ag}$ distance is 6.892(3) $\AA$. The free tetraimine macrocycle, $\mathrm{L}^{1}$, was obtained by treatment of $\left[\mathrm{Ag}_{2} \mathrm{~L}^{1}\right]\left(\mathrm{NO}_{3}\right)_{2}$ with an excess of iodide, and the reduced hexaaza derivative 7,22- $N, N^{\prime}$-dimethyl$3,7,11,18,22,26$-hexaazatricyclo[26.2.2 $\left.2^{1 \cdot 18} \cdot 2^{13.16}\right]$ tetratricosa-13,15,28,30,31,33decaene, $\mathrm{L}^{2}$, was prepared by reduction of $\left[\mathrm{Ag}_{2} \mathrm{~L}^{1}\right]\left(\mathrm{NO}_{3}\right)_{2}$ with $\mathrm{NaBH}_{4}$. The copper(II) complexes of the reduced ligand, $\left[\mathrm{Cu}_{2} \mathrm{Cl}_{2} \mathrm{~L}^{2}\right] \mathrm{Cl}_{2} \cdot \mathrm{CH}_{3} \mathrm{OH}$, $\left[\mathrm{Cu}_{2} \mathrm{Cl}_{2} \mathrm{~L}^{2}\right]\left(\mathrm{PF}_{6}\right)_{2}$ and $\left[\mathrm{Cu}_{2}\left(\mathrm{CH}_{3} \mathrm{CO}_{2}\right)_{2} \mathrm{~L}^{2}\right]\left(\mathrm{PF}_{6}\right)_{2} \cdot 4 \mathrm{H}_{2} \mathrm{O}$, have been prepared and characterized.
\end{abstract}

The construction of mono-, di- and polynuclear macrocyclic complexes by the cyclocondensation of diamines and dialdehydes using appropriate templating metal ions is a well established area of coordination chemistry. ${ }^{1}$ In the case of systems containing more than one metal ion, interest has focused on the study of electronic interactions between the metal ions ${ }^{2}$ or cooperative effects in terms of binding, and possibly even activation, ${ }^{3}$ of unusual species at the exogenous bridging sites created when two or more metal ions are bound by the macrocycle. An example of small molecule activation by the dicopper complex of a macrocyclic ligand has been reported by Martell and co-workers. ${ }^{4}$ This hexaaza hexadentate macrocycle ligand contains $m$-xylene spacers. In the presence of two equivalents of copper(I) and dioxygen, hydroxylation of one of the $m$-xylene spacers to give a phenolate group occurs. The resultant phenolato oxygen atom bridges between the two copper(II) ions in the product isolated form this reaction. A mechanism involving dioxygen activation by the dicopper(I) site was proposed.

Ligand modification influences the topology the macro-

* To whom correspondence should be addressed. cyclic complex and, often as a consequence of this, the reactivity of the metal ions. The present work concerns the preparation of the new hexadentate macrocycles related to the $m$-xylene-based ligands of Martell and co-workers, ${ }^{4}$ but instead the backbones contain $p$-xylene spacers. The new 30-membered hexadentate ligands, $\mathrm{L}^{1}$ and $\mathrm{L}^{2}$, are shown below. The present paper describes the preparation of $\mathrm{L}^{1}$ and $\mathrm{L}^{2}$ and a preliminary investigation of their coordination chemistry with silver and copper.

The parent non-methylated macrocycle $\mathrm{L}^{3}$ has been prepared previously by reduction of the product of the $2+2$ cyclocondensation of terephthalic aldehyde with bis(3-aminopropyl)amine (Fig. 1). ${ }^{5}$ The initial product of this reaction contains two imine groups and two 1,3aminal six-membered rings. Formation of the aminal rings is likely to be the driving force for this unusual reaction; the presence of metal templates or high dilution conditions are not necessary. Reduction of this product by $\mathrm{LiAlH}_{4}$ results in aminal ring opening and Schiff base reduction to give the hexaaza macrocycle $\mathrm{L}^{3}$. A synthetic route similar to that in Fig. 1 but using $N, N$-bis(3aminopropyl)methylamine is not possible for the preparation of $\mathrm{L}^{2}$, since formation of aminal rings is pre- 


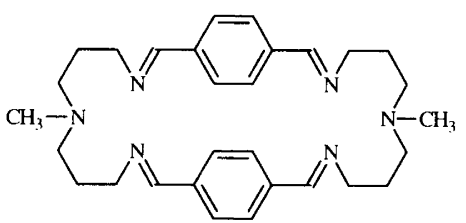

$\mathrm{L}^{1}$

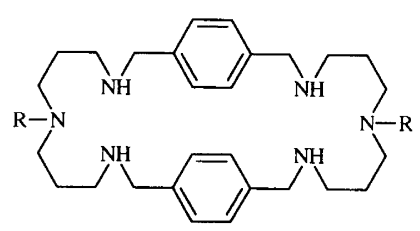

$\mathrm{L}^{2}: \mathrm{R}=\mathrm{CH}_{3} ; \mathrm{L}^{3}: \mathrm{R}=\mathrm{H}$
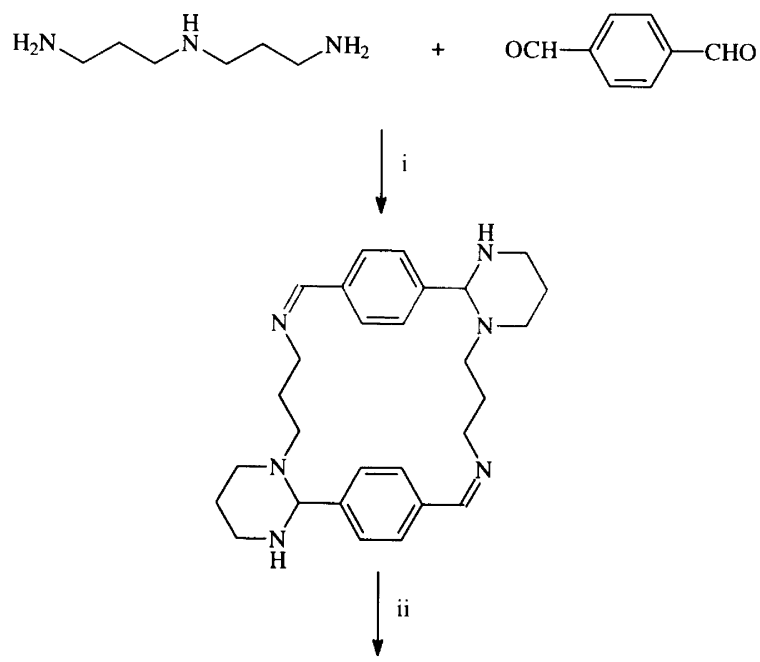

$\mathrm{L}^{3}$

Fig. 1. Synthetic route to the parent of $L^{2}$, the hexaaza macrocycle $\mathrm{L}^{3}$; (i) $0^{\circ} \mathrm{C}$, THF; (ii) $50^{\circ} \mathrm{C}, \mathrm{LiAlH}_{4}, \mathrm{THF}$, under Ar.

vented by the presence of the central tertiary amine group. The present paper describes an alternative approach of using silver to template the $2+2$ cyclocondensation of $N, N$-bis(3-aminopropyl)methylamine and terephthalic aldehyde. This method is advantageous in that the tetraimine macrocyle is produced and can be isolated as a free ligand after silver ion removal. The tetraimine macrocycle, $\mathrm{L}^{1}$, is expected to be more suitable than the hexaaza ligands $\mathrm{L}^{2}$ and $\mathrm{L}^{3}$ for the study of dinuclear complexes of 'soft' transition metal ions, e.g. dicopper(I) complexes. The reactivity of macrocyclic dicopper(I) complexes towards molecular oxygen is of particular interest.

\section{Experimental}

Physical measurements. IR spectra were measured as $\mathrm{KBr}$ discs using a Hitachi 270-30 IR spectrometer. UVvisible absorption spectra were recorded on a Shimadzu UV-3100 spectrophotometer. FAB mass spectrometry was carried out on a Kratos MS50TC instrument. NMR spectra were recorded on a Bruker AC 250. Elemental analyses were carried out by Atlantic Microlab Inc., GA. ESR measurements were carried out on powdered samples on a Bruker ESP-380EFT-EPR spectrometer at r.t.

( 7,22 - N,N' - Dimethyl-3,7,11,18,22,26- hexaazatricyclo$\left[26.2 .2^{1.18} \cdot 2^{13.16}\right.$ ] tetratricosa-2,11,13,15,17,26,28,30,31, 33-decaene) disilver $(\mathrm{I})$ dinitrate, $\left[\mathrm{Ag}_{2} \mathrm{~L}^{1}\right]\left(\mathrm{NO}_{3}\right)_{2}$. Terephthalaldehyde $(2.68 \mathrm{~g}, 20 \mathrm{mmol})$ and $N, N$-bis (3-aminopropyl)methylamine $(2.90 \mathrm{~g}, 20 \mathrm{mmol})$ were added to a $60{ }^{\circ} \mathrm{C}$ solution of $\mathrm{AgNO}_{3}(3.40 \mathrm{~g}, 20 \mathrm{mmol})$ in $\mathrm{MeOH}$ $(500 \mathrm{ml})$. After $2 \mathrm{~h}$ the product precipitated as goldenbrown crystals, which were isolated by filtration. Yield $5.8 \mathrm{~g}, 70.2 \%$. Anal. Found C, 43.44; H, 5.02; N, 13.48 . Calc. for $\mathrm{C}_{30} \mathrm{H}_{42} \mathrm{Ag}_{2} \mathrm{~N}_{8} \mathrm{O}_{6}$ : C, 43.60; H, 5.12; N, 13.56 . FABMS, $m / z: 764\left(\left[\mathrm{Ag}_{2} \mathrm{~L}^{1}\left(\mathrm{NO}_{3}\right)\right]^{+}, 40 \%\right), 593\left(\left[\mathrm{AgL}^{1}\right]^{+}\right.$, 100). ${ }^{1} \mathrm{H} \quad \mathrm{NMR}$ (DMSO- $\left.d_{6}\right): \delta=1.86 \quad$ (q, $8 \mathrm{H}$, $\left.\mathrm{CH}_{2} \mathrm{CH}_{2} \mathrm{CH}_{2}\right), 2.21\left(\mathrm{~s}, 6 \mathrm{H}, \mathrm{CH}_{3}\right), 2.50[\mathrm{t}, 8 \mathrm{H}$, $\left.\mathrm{N}\left(\mathrm{CH}_{3}\right) \mathrm{CH}_{2}\right], 3.83\left(\mathrm{t}, 8 \mathrm{H}, \mathrm{NHCH}_{2}\right), 7.89(\mathrm{~s}, 8 \mathrm{H}$, $\left.\mathrm{C}_{6} H_{4}\right), 8.55(\mathrm{~s}, 4 \mathrm{H}, \mathrm{CH}) .{ }^{13} \mathrm{C}$ NMR (DMSO- $\left.d_{6}\right): \delta=$ $28.08\left(\mathrm{CH}_{2} \mathrm{CH}_{2} \mathrm{CH}_{2}\right), 40\left[\mathrm{CH}_{3}\right.$ (hidden in DMSO)], $55.26\left[\mathrm{~N}\left(\mathrm{CH}_{3}\right) \mathrm{CH}_{2}\right], 59.14\left(\mathrm{NHCH}_{2}\right), 128.14$ (phenylene $\mathrm{CH}$ ), 137.36 (phenylene $C$ ), $163.63(\mathrm{CH})$. Crystals for $\mathrm{X}$-ray data collection were obtained by recrystallization from methanol/benzene $(4: 1 \mathrm{v} / \mathrm{v})$.

7,22 - N,N' - Dimethyl - 3,7,11,18,22,26 - hexaazatricyclo$\left[26.2 \cdot 2^{1.18} \cdot 2^{13.16}\right]$ tetratricosa $-2,11,13,15,17,26,28,30,31$, 33-decaene, $\mathrm{L}^{1} \cdot \mathrm{CH}_{2} \mathrm{Cl}_{2}$. KI $(260 \mathrm{mg}, 1.56 \mathrm{mmol})$ was added to a solution of $\left[\mathrm{Ag}_{2} \mathrm{~L}^{1}\right]\left(\mathrm{NO}_{3}\right)_{2} \quad(400 \mathrm{mg}$, $0.484 \mathrm{mmol})$ in $\mathrm{MeOH}(200 \mathrm{ml})$. After $10 \mathrm{~min}$ AgI was removed by filtration and the solution was evaporated to dryness. The residue was resuspended in $\mathrm{CH}_{2} \mathrm{Cl}_{2}$ $(30 \mathrm{ml})$, and the undissolved material was removed by filtration. The solution was evaporated to a brown oil, which was placed under vacuum for $24 \mathrm{~h}$. Yield $114 \mathrm{mg}$, $48.4 \%$ of a oily yellow solid. Anal. Found C, 64.74; H, 7.48; N, 14.53. Calc. for $\mathrm{C}_{31} \mathrm{H}_{44} \mathrm{~N}_{6} \mathrm{Cl}_{2}: \mathrm{C}, 65.14 ; \mathrm{H}, 7.76$; $\mathrm{N}, 14.70$. FABMS, $m / z$ : $487\left(\mathrm{~L}^{1} \mathrm{H}^{+}, 100 \%\right)$. ${ }^{1} \mathrm{H}$ NMR $\left(\mathrm{CDCl}_{3}\right): \delta=1.86\left(\mathrm{~m}, 8 \mathrm{H}, \mathrm{CH}_{2} \mathrm{CH}_{2} \mathrm{CH}_{2}\right), 2.23(\mathrm{~s}, 6 \mathrm{H}$, $\left.\mathrm{CH}_{3}\right), 2.43\left[\mathrm{~m}, 8 \mathrm{H}, \mathrm{N}\left(\mathrm{CH}_{3}\right) \mathrm{CH}_{2}\right], 3.63(\mathrm{t}, 8 \mathrm{H}$, $\left.\mathrm{NHCH}_{2}\right), 7.56,7.72\left(2 \times \mathrm{s}, 8 \mathrm{H}, \mathrm{C}_{6} H_{4}\right), 8.19,8.27(2 \times \mathrm{s}$, $4 \mathrm{H}, \quad \mathrm{CH}) .{ }^{13} \mathrm{C} \quad \mathrm{NMR} \quad\left(\mathrm{CDCl}_{3}\right): \quad \delta=28.31,28.80$ $\left(\mathrm{CH}_{2} \mathrm{CH}_{2} \mathrm{CH}_{2}\right), \quad 42.48, \quad 42.61 \quad\left(\mathrm{CH}_{3}\right), \quad 54.49, \quad 55.72$ $\left(\mathrm{N}\left(\mathrm{CH}_{3}\right) \mathrm{CH}_{2}\right), 58.76,60.06\left(\mathrm{NHCH}_{2} \mathrm{CH}_{2}\right), 128.46$, 128.55 (phenylene $\mathrm{CH}$ ), 138.33, 138.43 (phenylene $C$ ), $160.83,161.02(\mathrm{CH})$.

7,22 - N,N' - Dimethyl - 3,7,11,18,22,26 - hexaazatricyclo[26.2.2 $2^{1.18} .2^{13.16}$ ] tetratricosa $-13,15,28,30,31,33$-decaene, $L^{2}$. $\mathrm{NaBH}_{4}(4.5 \mathrm{~g}, 0.119 \mathrm{~mol})$ was added to a suspension of $\left[\mathrm{Ag}_{2} \mathrm{~L}^{1}\right]\left(\mathrm{NO}_{3}\right)_{2}(1.818 \mathrm{~g}, 2.2 \mathrm{mmol})$ in DMF $(100 \mathrm{ml})$ and $\mathrm{MeOH}(50 \mathrm{ml})$ in three portions over a period of $1 \mathrm{~h}$. The mixture was stirred at r.t. for a further $1 \mathrm{~h}$, after which time the suspension was acidified to $\mathrm{pH} 4$ with $4 \mathrm{M} \mathrm{H}_{2} \mathrm{SO}_{4}$ and evaporated to dryness. The solid was resuspended in $\mathrm{MeOH}(400 \mathrm{ml})$ and undissolved material was removed by filtration. The resultant solution was 
evaporated to dryness, redissolved in $\mathrm{H}_{2} \mathrm{O}(100 \mathrm{ml})$ and extracted with chloroform $(3 \times 20 \mathrm{ml})$. The combined chloroform extracts were dried over anhydrous $\mathrm{Na}_{2} \mathrm{SO}_{4}$ and evaporated to dryness. The solid was extracted by means of a Soxhlet apparatus with low boiling petroleum. Yield 1.09 g, 58\%. Anal. Found C, 71.94; H, 10.16; N, 16.79. Calc. for $\mathrm{C}_{30} \mathrm{H}_{50} \mathrm{~N}_{6}$ : C, 72.83; H, 10.19; N, 16.99. FABMS, $m / z: 495\left(\mathrm{~L}^{2} \mathrm{H}^{+}, 100 \%\right) .{ }^{1} \mathrm{H}$ NMR (DMSO$\left.d_{6}\right): \delta=1.63\left(\mathrm{k}, 8 \mathrm{H}, \mathrm{CH}_{2} \mathrm{CH}_{2} \mathrm{CH}_{2}\right), 2.18\left(\mathrm{~s}, 6 \mathrm{H}, \mathrm{CH}_{3}\right)$, $2.35\left[\mathrm{t}, 8 \mathrm{H}, \mathrm{N}\left(\mathrm{CH}_{3}\right) \mathrm{CH}_{2}\right], 2.62\left(\mathrm{t}, 8 \mathrm{H}, \mathrm{NHCH}_{2} \mathrm{CH}_{2}\right)$, $3.67\left(\mathrm{~s}, 8 \mathrm{H}, \mathrm{C}_{6} \mathrm{H}_{4} \mathrm{CH}_{2}\right), 7.23\left(\mathrm{~s}, 8 \mathrm{H}, \mathrm{C}_{6} \mathrm{H}_{4}\right) .{ }^{13} \mathrm{C} \mathrm{NMR}$ (DMSO- $\left.d_{6}\right): \delta=27.58\left(\mathrm{CH}_{2} \mathrm{CH}_{2} \mathrm{CH}_{2}\right), 42.65\left(\mathrm{CH}_{3}\right)$, $48.56 \quad\left(\mathrm{C}_{6} \mathrm{H}_{4} \mathrm{CH}_{2}\right), \quad 54.12 \quad\left[\mathrm{~N}\left(\mathrm{CH}_{3}\right) \mathrm{CH}_{2}\right], \quad 56.6$ $\left(\mathrm{NHCH}_{2} \mathrm{CH}_{2}\right.$ ), 128.51 (phenylene $\mathrm{CH}$ ), 139.57 (phenylene $C$ ).

[( 7,22 - N, N'-Dimethyl-3,7,11,18,22,26-hexaazatricyclo$\left[26.2 .2^{1.18} \cdot 2^{13.16}\right.$ ] tetratricosa-13,15,28,30,31,33-decaene)dicopper(II) dichloro] dichloride, $\left[\mathrm{Cu}_{2} \mathrm{Cl}_{2} \mathrm{~L}^{2}\right] \mathrm{Cl}_{2} \cdot \mathrm{CH}_{3} \mathrm{OH}$. $\mathrm{CuCl}_{2} \cdot 2 \mathrm{H}_{2} \mathrm{O}(17.8 \mathrm{mg}, 104.41 \mu \mathrm{mol})$ in $\mathrm{MeOH}(1 \mathrm{ml})$ was added to $\mathrm{L}^{2}(25 \mathrm{mg}, 50.6 \mu \mathrm{mol})$ in $\mathrm{MeOH}(2 \mathrm{ml})$. After $5 \mathrm{~min}$ the precipitated turquoise microcrystalline solid was isolated by filtration. Yield $31 \mathrm{mg}, 77.3 \%$. Anal. Found $\mathrm{C}, 46.76 ; \mathrm{H}, 6.19 ; \mathrm{N}, 10.72$. Calc. for $\mathrm{C}_{31} \mathrm{H}_{54} \mathrm{Cl}_{4} \mathrm{Cu}_{2} \mathrm{~N}_{6} \mathrm{O}: \mathrm{C}, 46.79 ; \mathrm{H}, 6.84 ; \mathrm{N}, 10.56$. UV-Vis (DMSO) $\lambda / \mathrm{nm}\left(\varepsilon / \mathrm{dm}^{3} \mathrm{~mol}^{-1} \mathrm{~cm}^{-1}\right): 292$ (9390), 703 (370). FABMS, $m / z$ : $692\left(\left[\mathrm{Cu}_{2} \mathrm{Cl}_{2} \mathrm{~L}^{2}\right]^{+}, 12 \%\right), 655$ $\left(\left[\mathrm{Cu}_{2} \mathrm{ClL}^{2}\right]^{+}, \quad 31\right), \quad 592 \quad\left(\left[\mathrm{Cu}_{2} \mathrm{ClL}^{2}\right]^{+}, \quad 68\right), \quad 557$ $\left(\left[\mathrm{Cu}_{2} \mathrm{~L}^{2}\right]^{+}, 100\right)$.

[( 7,22 - N, N'-Dimethyl-3,7,11,18,22,26-hexaazatricyclo$\left[26.2 .2^{1.18} \cdot 2^{13.16}\right]$ tetratricosa-13,15,28,30,31,33-decaene)dicopper (II) dichloro] di-hexafluorophosphate, $\left[\mathrm{Cu}_{2} \mathrm{Cl}_{2} \mathrm{~L}^{2}\right]$ $\left(P F_{6}\right)_{2} . \mathrm{NH}_{4} \mathrm{PF}_{6}(33.0 \mathrm{mg}, 202 \mu \mathrm{mol})$ in $\mathrm{MeOH}(2 \mathrm{ml})$ was added to a solution of $\mathrm{CuCl}_{2} \cdot 2 \mathrm{H}_{2} \mathrm{O}(17.2 \mathrm{mg}$, $101 \mu \mathrm{mol})$ and $\mathrm{L}^{2}(25 \mathrm{mg}, 51 \mu \mathrm{mol})$ in $\mathrm{MeOH}(20 \mathrm{ml})$. The turquoise microcrystals were isolated by filtration and washed with $\mathrm{MeOH}(1 \mathrm{ml})$. Yield $41 \mathrm{mg}, 83 \%$. Anal. Found $\mathrm{C}, 37.11 ; \mathrm{H}, 5.22 ; \mathrm{N}$, 8.54. Calc. for $\mathrm{C}_{30} \mathrm{H}_{50} \mathrm{Cl}_{2} \mathrm{Cu}_{2} \mathrm{~F}_{12} \mathrm{~N}_{6} \mathrm{P}_{2}$ : C, 36.67; H, 5.13; N, 8.55. UV-Vis (DMSO) $\lambda / \mathrm{nm} \quad\left(\varepsilon / \mathrm{dm}^{3} \mathrm{~mol}^{-1} \mathrm{~cm}^{-1}\right): 295$ (8810), $700(410)$. FABMS, $m / z: 655\left(\left[\mathrm{Cu}_{2} \mathrm{ClL}^{2}\right]^{+}, 30 \%\right)$, $592\left(\left[\mathrm{Cu}_{2} \mathrm{ClL}^{2}\right]^{+}, 5\right), 557\left(\left[\mathrm{Cu}_{2} \mathrm{~L}^{2}\right]^{+}, 100\right)$.

[( 7,22-N,N' Dimethyl-3,7,11,18,22,26-hexaazatricyclo[26.2.2 $2^{1.18} \cdot 2^{13.16}$ ] tetratricosa-13,15,28,30,31,33-decaene)dicopper(II)diacetato]dihexafluorophosphate, $\quad\left[\mathrm{Cu}_{2}\left(\mathrm{CH}_{3}{ }^{-}\right.\right.$ $\left.\mathrm{CO}_{2}\right)_{2} \mathrm{~L}^{2} J\left(\mathrm{PF}_{6}\right)_{2} \cdot 4 \mathrm{H}_{2} \mathrm{O} . \mathrm{NH}_{4} \mathrm{PF}_{6}(81 \mathrm{mg}, 497 \mu \mathrm{mol})$ was added to a solution of $\mathrm{L}^{2}(50 \mathrm{mg}, 101 \mu \mathrm{mol})$ and $\mathrm{Cu}\left(\mathrm{CH}_{3} \mathrm{CO}_{2}\right) \cdot 2 \mathrm{H}_{2} \mathrm{O} \quad(55.4 \mathrm{mg}, 277 \mu \mathrm{mol})$ in $\mathrm{MeOH}$ $(4 \mathrm{ml})$ and water $(0.5 \mathrm{ml})$. After standing overnight the blue crystals were isolated by filtration. Yield $74.7 \mathrm{mg}, 67 \%$. Anal. Found $\mathrm{C}, 37.16 ; \mathrm{H}, 5.30 ; \mathrm{N}, 7.48$. Calc. for $\mathrm{C}_{34} \mathrm{H}_{64} \mathrm{Cu}_{2} \mathrm{~F}_{12} \mathrm{~N}_{6} \mathrm{O}_{8} \mathrm{P}_{2}: \mathrm{C}, 37.06 ; \mathrm{H}, 5.85 ; \mathrm{N}, 7.48$. UV-Vis (DMSO) $\lambda / \mathrm{nm}\left(\varepsilon / \mathrm{dm}^{3} \mathrm{~mol}^{-1} \mathrm{~cm}^{-1}\right): 292(8850), 699(440)$. FABMS, $m / z: 825\left(\left[\mathrm{Cu}_{2}\left(\mathrm{CH}_{3} \mathrm{CO}_{2}\right) \mathrm{L}^{2}\left(\mathrm{PF}_{6}\right)\right]^{+}, 8 \%\right), 765$ $\left(\left[\mathrm{Cu}_{2}\left(\mathrm{CH}_{3} \mathrm{CO}_{2}\right) \mathrm{L}^{2}\left(\mathrm{PF}_{6}\right) \mathrm{H}_{2}\right]^{+}, 100\right), 679\left(\left[\mathrm{Cu}_{2}\left(\mathrm{CH}_{3} \mathrm{CO}_{2}\right)-\right.\right.$ $\left.\left.\mathrm{L}^{2}\right]^{+}, 5\right), 617\left(\left[\mathrm{Cu}_{2}\left(\mathrm{CH}_{3} \mathrm{CO}_{2}\right) \mathrm{L}^{2} \mathrm{H}\right]^{+}, 57\right), 557\left(\left[\mathrm{Cu}_{2} \mathrm{~L}^{2}\right]^{+}\right.$, $82)$.
$X$-Ray techniques. Crystal and experimental data for $\left[\mathrm{Ag}_{2} \mathrm{~L}^{1}\right]\left(\mathrm{NO}_{3}\right)_{2}$ are listed in Table 1 . The crystal was cooled to $120 \mathrm{~K}$ using the Cryostream nitrogen gas cooler system. ${ }^{6}$ Four standard reflections were measured for intensity and orientation control after every $4 \mathrm{~h}$. No decay in intensities was observed. The intensities were corrected for Lorentz and polarization effects. Absorption correction was carried out by an empirical method, ${ }^{7}$ in which the crystal shape is approximated by an ellipsoid and the size (in units of $\mu \mathrm{m}^{-1}$ ) and orientation are treated as parameters. The refinement of the parameters is based on $\psi$-scans on 4 reflections and symmetry equivalents, which amounts to 145 observations. The structure was solved by the Patterson method

Table 1. Crystallographic data and details of structural determination for $\left[\mathrm{Ag}_{2} \mathrm{~L}^{1}\right]\left(\mathrm{NO}_{3}\right)_{2}$.

\begin{tabular}{|c|c|}
\hline Formula & $\mathrm{C}_{30} \mathrm{H}_{42} \mathrm{~N}_{6} \mathrm{O}_{6} \mathrm{Ag}_{2}$ \\
\hline Formula weight & 826.46 \\
\hline Crystal system & Monoclinic \\
\hline Space group & $P 21 / c$ \\
\hline \multicolumn{2}{|l|}{ Unit-cell dimensions: } \\
\hline$a / \AA$ & $14.153(6)$ \\
\hline$b / \AA$ & $12.263(4)$ \\
\hline$c / \AA$ & $9.220(2)$ \\
\hline$\beta / /^{\circ}$ & $97.52(3)$ \\
\hline Unit-cell volume, $V / \AA^{3}$ & $1586.4(9)$ \\
\hline Formula units per unit cell, $Z$ & 2 \\
\hline$F(000)$ & 840 \\
\hline Calculated density $D_{x} / \mathrm{g} \mathrm{cm}^{-3}$ & 1.73 \\
\hline Radiation & Mo $K \alpha$ \\
\hline Wavelength, $\lambda / \AA$ & 0.71073 \\
\hline Linear absorption coefficient $/ \mathrm{mm}^{-1}$ & 1.29 \\
\hline Temperature, $T / \mathrm{K}$ & 120 \\
\hline Crystal description & Golden-brown \\
\hline Crystal size $/ \mathrm{mm}$ & $0.14 \times 0.14 \times 0.08$ \\
\hline Diffractometer & Enraf-Nonius CAD-4F \\
\hline \multicolumn{2}{|l|}{ Unit-cell determination: } \\
\hline No. of reflections used & 25 \\
\hline$\theta$-Range $/^{\circ}$ & $8.0-12.8$ \\
\hline \multicolumn{2}{|l|}{ Intensity data collection: } \\
\hline$\theta_{\max } /^{\circ}$ & 30 \\
\hline Range of $h$ & $-19-0$ \\
\hline Range of $k$ & $-17-0$ \\
\hline Range of $I$ & $-12-12$ \\
\hline Scan mode & $\omega$ \\
\hline Scan range, $\Delta \omega$ & $2.15+0.35 \tan \theta$ \\
\hline Total number of unique reflections & 4614 \\
\hline No. of independent reflections, & \\
\hline$[I>2 \sigma(I)]$ & 3646 \\
\hline Corrections & Lorenz-polarization absorption \\
\hline Transmission factors & $0.8471-0.7952$ \\
\hline \multicolumn{2}{|l|}{ Structure refinement: } \\
\hline Minimization of & $\Sigma w\left(\left|F_{\mathrm{o}}\right|^{2}-\left|F_{\mathrm{c}}\right|^{2}\right)^{2}$ \\
\hline Anisotropic thermal parameters & All non-hydrogen atoms \\
\hline Isotropic thermal parameters & Hydrogen atoms \\
\hline No. of refined parameters & 292 \\
\hline Weighting scheme & $\begin{array}{l}{\left[\sigma^{2}\left(F_{\mathrm{o}}^{2}\right)+(0.0198 P)^{2}+2.28 P\right]^{-1}} \\
\quad P=\left(F_{\mathrm{o}}^{2}+2 F_{\mathrm{c}}^{2}\right) / 3\end{array}$ \\
\hline$R=\Sigma|| F_{\mathrm{o}}|-| F_{\mathrm{c}}|| / \Sigma\left|F_{\mathrm{o}}\right|$ & 0.0367 (3646 reflections) \\
\hline $\begin{array}{l}w R 2=\left[\Sigma w\left|F_{o}^{2}-F_{c}^{2}\right|^{2} / \Sigma w F_{o}^{4}\right]^{1 / 2} \\
S=\left[\Sigma w\left(\left|F_{o}\right|^{2}-\left|F_{c}\right|^{2}\right)^{2} /\right.\end{array}$ & 0.0699 (4614 reflections) \\
\hline$\left.\left(N_{\text {obs }}-N_{\text {var }}\right)\right]^{1 / 2}$ & 1.10 \\
\hline Final $(\Delta / \sigma)_{\max }$ & 0.12 \\
\hline Final $\Delta \rho_{\min }$ and $\Delta \rho_{\max } / e \AA^{-3}$ & -1.09 and 0.67 \\
\hline
\end{tabular}


with partial structure expansion and refined by a fullmatrix least-squares technique. All non-hydrogen atoms were refined anisotropically. The hydrogen atoms could all be located in the difference maps and were refined with fixed thermal parameters $U(\mathrm{H})=1.2 U$ for attached atoms. The crystallographic computations were performed with SHELXS86 ${ }^{8}$ and SHELXL93. ${ }^{9}$ The atomic scattering factors were taken from the literature. ${ }^{10}$ The SHELXTL program ${ }^{11}$ was used for illustration and PLATON $^{12}$ for molecular geometry calculations.

The final positional parameters are listed in Table 2. Anisotropic thermal parameters, positional parameters for the hydrogen atoms and a list of observed and calculated structure factors may be obtained from one of the authors (I.S.) on request.

\section{Results and discussion}

Syntheses. The $2+2$ Schiff base cyclocondensation of 1,4-terephthalaldehyde and $N, N$-bis(3-aminopropyl)methylamine in the absence of silver leads to intractable sticky products. The mass spectra of these materials show peaks due to several of the expected oligomeric products. By contrast, if the reaction is carried out in the presence of silver nitrate, a disilver complex of the tetra-Schiff base macrocycle $\mathrm{L}^{1},\left[\mathrm{Ag}_{2} \mathrm{~L}^{1}\right]\left(\mathrm{NO}_{3}\right)_{2}$, is isolated in a $70 \%$ yield. $\left[\mathrm{Ag}_{2} \mathrm{~L}^{1}\right]\left(\mathrm{NO}_{3}\right)_{2}$ was used as starting material for preparation of the free ligand $7,22-N, N^{\prime}$ dimethyl-3,7,11,18,22,26-hexaazatricyclo[26.2.2 $\left.2^{1.18} \cdot 2^{13.16}\right]$ tetratricosa-2,11,13,15,17,26,28,30,31,33-decaene, $\mathrm{L}^{1}$, and the reduced macrocyclic ligand dimethyl-3,7,

Table 2. Fractional atomic coordinates and equivalent isotropic thermal parameters (in $\AA^{2}$ ) for $\left[\mathrm{Ag}_{2} \mathrm{~L}^{1}\right]\left(\mathrm{NO}_{3}\right)_{2}$.

\begin{tabular}{llcll}
\hline Atom & $x$ & $y$ & \multicolumn{1}{l}{$z$} & \multicolumn{1}{l}{$U_{\text {eq }}{ }^{a}$} \\
\hline $\mathrm{Ag}$ & $0.30655(2)$ & $0.01152(2)$ & $0.19086(2)$ & $0.0153(1)$ \\
$\mathrm{N}(1)$ & $0.32431(16)$ & $-0.15071(19)$ & $0.2864(3)$ & $0.0135(6)$ \\
$\mathrm{N}(2)$ & $0.12575(14)$ & $0.0026(2)$ & $0.2510(2)$ & $0.0144(6)$ \\
$\mathrm{N}(3)$ & $0.28444(16)$ & $0.18673(19)$ & $0.1630(3)$ & $0.0139(6)$ \\
$\mathrm{C}(1)$ & $0.2540(2)$ & $-0.1691(2)$ & $0.3896(3)$ & $0.0157(7)$ \\
$\mathrm{C}(2)$ & $0.1551(2)$ & $-0.1952(2)$ & $0.3106(3)$ & $0.0178(8)$ \\
$\mathrm{C}(3)$ & $0.1125(2)$ & $-0.1104(2)$ & $0.1990(3)$ & $0.0171(8)$ \\
$\mathrm{C}(4)$ & $0.0767(2)$ & $0.0194(3)$ & $0.3804(3)$ & $0.0218(8)$ \\
$\mathrm{C}(5)$ & $0.0880(2)$ & $0.0776(2)$ & $0.1329(3)$ & $0.0159(8)$ \\
$\mathrm{C}(6)$ & $0.1089(2)$ & $0.1973(3)$ & $0.1704(4)$ & $0.0196(8)$ \\
$\mathrm{C}(7)$ & $0.2090(2)$ & $0.2218(2)$ & $0.2488(3)$ & $0.0176(8)$ \\
$\mathrm{C}(8)$ & $0.32740(19)$ & $0.2624(2)$ & $0.1033(3)$ & $0.0132(7)$ \\
$\mathrm{C}(9)$ & $0.40315(19)$ & $0.2475(2)$ & $0.0104(3)$ & $0.0126(7)$ \\
$\mathrm{C}(10)$ & $0.4477(2)$ & $0.3418(2)$ & $-0.0328(3)$ & $0.0151(7)$ \\
$\mathrm{C}(11)$ & $0.5188(2)$ & $0.3351(2)$ & $-0.1226(3)$ & $0.0146(7)$ \\
$\mathrm{C}(12)$ & $0.54825(19)$ & $0.2332(2)$ & $-0.1689(3)$ & $0.0133(7)$ \\
$\mathrm{C}(13)$ & $0.50257(19)$ & $0.1397(2)$ & $-0.1273(3)$ & $0.0140(7)$ \\
$\mathrm{C}(14)$ & $0.43088(19)$ & $0.1461(2)$ & $-0.0393(3)$ & $0.0140(7)$ \\
$\mathrm{C}(15)$ & $0.37711(19)$ & $-0.2324(2)$ & $0.2656(3)$ & $0.0138(7)$ \\
$\mathrm{N}$ & $0.24436(17)$ & $-0.02385(19)$ & $-0.1922(3)$ & $0.0176(7)$ \\
$\mathrm{O}(1)$ & $0.29477(17)$ & $-0.01533(18)$ & $-0.2933(2)$ & $0.0300(7)$ \\
$\mathrm{O}(2)$ & $0.27965(17)$ & $-0.06464(17)$ & $-0.0722(2)$ & $0.0242(6)$ \\
$\mathrm{O}(3)$ & 0.16022 & $0.0077(2)$ & $-0.2098(3)$ & $0.0380(8)$ \\
\hline
\end{tabular}

${ }^{a} U_{\mathrm{eq}}=\frac{1}{3} \sum_{i} \sum_{j} U_{i j} a_{i}^{*} a_{j}^{*} a_{i} \cdot a_{j}$ $11,18,22,26$-hexaazatricyclo[ $\left[26.2 .2^{1.18} \cdot 2^{13.16}\right]$ tetratricosa$13,15,28,30,31,33$-decaene, $L^{2}$. The synthetic route to the disilver complex and the two macrocycles, $\mathrm{L}^{1}$ and $\mathrm{L}^{2}$, derived from this complex is depicted in Fig. 2. Isolation of the free ligand was accomplished by the removal of the silver ions in $\left[\mathrm{Ag}_{2} \mathrm{~L}^{1}\right]\left(\mathrm{NO}_{3}\right)_{2}$ using excess iodide ions. The doubling up of signals in the NMR spectrum of $\mathrm{L}^{1}$ compared to the NMR spectrum of $\left[\mathrm{Ag}_{2} \mathrm{~L}^{1}\right]\left(\mathrm{NO}_{3}\right)_{2}$ suggest the presence of at least two geometrical isomers of the free Schiff base, probably due to inversion about one or more of the imine nitrogen atoms. The reduced macrocycle, $\mathrm{L}^{2}$, was isolated after reduction of the silver complex by $\mathrm{NaBH}_{4}$ in methanol. In this reaction the four imine groups and the silver(I) are reduced to amines and metallic silver, respectively. As a result the silver is effectively removed from the macrocycle. Dinuclear copper(II) complexes were prepared and characterised using $\mathrm{L}^{2}$, vide infra.

Silver complex. $X$-Ray crystal structure of $\left[\mathrm{Ag}_{2} \mathrm{~L}^{1}\right]$ $\left(\mathrm{NO}_{3}\right)_{2}$. Selected bond distances and angles are summarized in Table 3. The structure of $\left[\mathrm{Ag}_{2} \mathrm{~L}^{1}\right]\left(\mathrm{NO}_{3}\right)_{2}$ is shown in Fig. 3. The cation contains a crystallogaphic centre of symmetry. The silver ions are coordinated to two imine nitrogen atoms at each end of the macrocycle, the $\mathrm{Ag}-\mathrm{N}(1)$ and the $\mathrm{Ag}-\mathrm{N}(3)$ bonds being 2.177(3) and 2.182(3) $\AA$, respectively. There are close interactions of each silver ion to the oxygen atom of a nitrate anion $[\mathrm{Ag}-\mathrm{O}(2)=2.580(2) \AA]$, and to the tertiary amine nitrogen atoms $[\mathrm{Ag}-\mathrm{N}(2)=2.690(2) \AA]$. The Ag atoms are situated $0.63 \AA$ above the plane of the $p$-xylyl rings. The two planes of these rings are parallel with a separation of $1.9 \AA$ between the planes. The shortest distance between the two xylyl rings is $\mathrm{C}(13) \cdots \mathrm{C}(14)$ $[1-x,-y,-z]$ at a distance of $3.892(4) \AA$. The $\mathrm{Ag} \cdots \mathrm{Ag}$ separation is $6.892(3) \AA$.

It is interesting to compare the structure of the present complex $\left[\mathrm{L}^{1} \mathrm{Ag}_{2}\right]\left(\mathrm{NO}_{3}\right)_{2}$ with that of a dicopper complex of the non-methylated saturated macrocyclic analogue, $\mathrm{L}^{3}{ }^{13}$ The interatomic metal-metal separation in $\left[\mathrm{Ag}_{2} \mathrm{~L}^{1}\right]\left(\mathrm{NO}_{3}\right)_{2}$ is significantly smaller than that measured for $\left[\mathrm{Cu}_{2}\left(\mathrm{CH}_{3} \mathrm{CO}_{2}\right)_{2} \mathrm{~L}^{3}\right]\left(\mathrm{ClO}_{4}\right)_{2}(8.40 \AA) .{ }^{13}$ The most significant chemical difference in the two macrocyles is the presence of four secondary amine groups in $\mathrm{L}^{3}$ as opposed to the four imine groups in $\mathrm{L}^{1}$. This apparently has a profound effect on the topology of the two complexes. $\pi$-Conjugation of the xylyl groups with the para imine groups imposes their coplanarity in the structure of $\left[\mathrm{Ag}_{2} \mathrm{~L}^{1}\right]\left(\mathrm{NO}_{3}\right)_{2}$, whereas the presence of amine groups in the same position in the case of $\mathrm{L}^{3}$ gives more flexibility due to the fact that rotation about the four aryl- $\mathrm{CH}_{2}$ bonds is possible. Hence, in the structure of $\left[\mathrm{Cu}_{2}\left(\mathrm{CH}_{3} \mathrm{CO}_{2}\right)_{2} \mathrm{~L}^{3}\right]\left(\mathrm{ClO}_{4}\right)_{2}$ a cleft is created in which the benzene rings are stacked with an interplanar distance of $3.8 \AA$ on opposite sides of the cleft. This is an essentially $90^{\circ}$ twist in the orientation of the benzene groups in the dicopper complex of $\mathrm{L}^{3}$ compared to the disilver complex of $\mathrm{L}^{1}$. A schematic depiction of the 


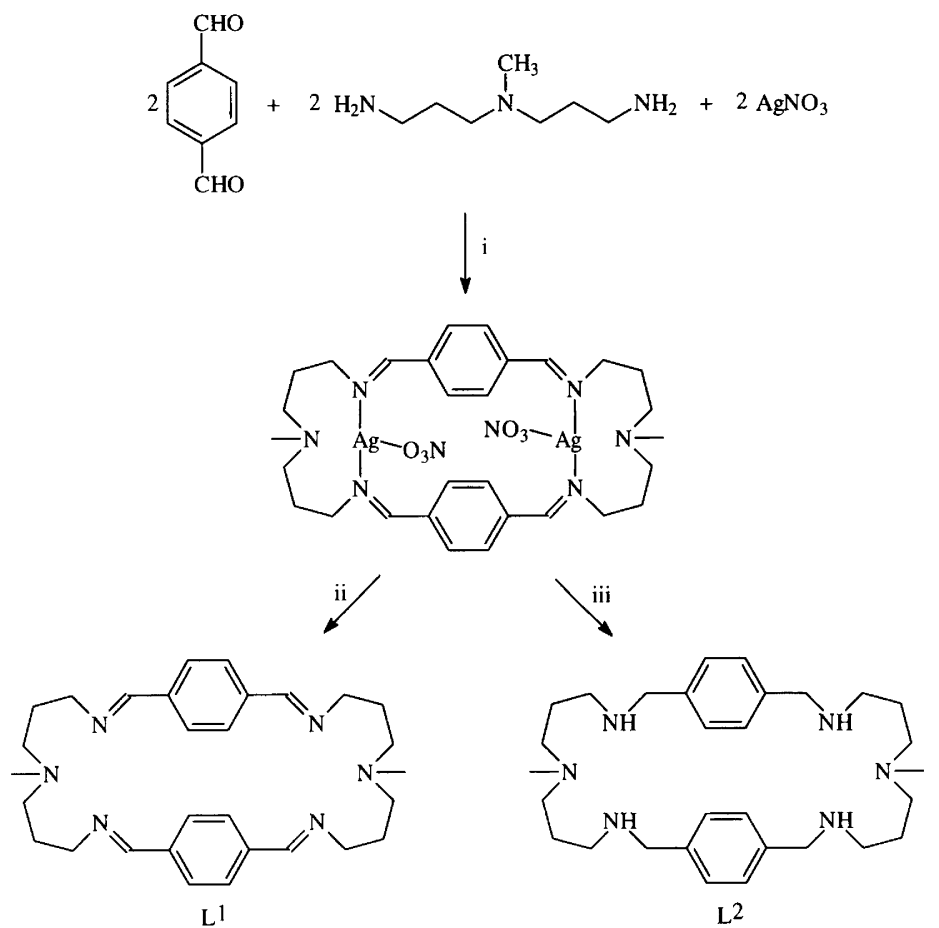

Fig. 2. Synthetic route to the dinuclear silver complex $\left[\mathrm{Ag}_{2} \mathrm{~L}^{1}\right]\left(\mathrm{NO}_{3}\right)_{2}$, the free Schiff base ligand $\mathrm{L}^{1}$ and its reduced derivative $\mathrm{L}^{2}$. (i) $\mathrm{MeOH}, 60^{\circ} \mathrm{C}, 2 \mathrm{~h}$; (ii) $\mathrm{KI}, \mathrm{MeOH}$ and (iii) $\mathrm{NaBH}_{4}, \mathrm{MeOH} / \mathrm{DMF}$.

Table 3. Selected bond distances (in $\AA$ ) and angles (in ${ }^{\circ}$ ) for $\left[\mathrm{Ag}_{2} \mathrm{~L}^{1}\right]\left(\mathrm{NO}_{3}\right)_{2}$.

\begin{tabular}{|c|c|c|c|}
\hline $\mathrm{Ag}-\mathrm{N}(1)$ & $2.177(2)$ & $A g-N(3)$ & $2.182(2)$ \\
\hline $\mathrm{Ag} \cdots \mathrm{O}(2)$ & $2.580(2)$ & $\mathrm{Ag} \cdots \mathrm{N}(2)$ & $2.691(2)$ \\
\hline$N(1)-C(15)^{i}$ & $1.280(3)$ & $N(1)-C(1)$ & $1.481(3)$ \\
\hline$N(2)-C(4)$ & $1.471(3)$ & $N(2)-C(3)$ & $1.470(4)$ \\
\hline$N(3)-C(7)$ & $1.474(3)$ & $N(2)-C(5)$ & $1.472(4)$ \\
\hline$C(1)-C(2)$ & $1.526(4)$ & $N(3)-C(8)$ & $1.274(4)$ \\
\hline$C(5)-C(6)$ & $1.528(4)$ & $C(2)-C(3)$ & $1.529(4)$ \\
\hline$C(8)-C(9)$ & $1.468(4)$ & $C(6)-C(7)$ & $1.533(4)$ \\
\hline$C(9)-C(14)$ & $1.398(4)$ & $C(9)-C(10)$ & $1.400(4)$ \\
\hline$C(11)-C(12)$ & $1.402(4)$ & $C(10)-C(11)$ & $1.387(4)$ \\
\hline$C(12)-C(15)$ & $1.468(4)$ & $C(12)-C(13)$ & $1.395(4)$ \\
\hline $\mathrm{O}(1)-\mathrm{N}$ & $1.250(3)$ & $C(13)-C(14)$ & $1.382(4)$ \\
\hline $\mathrm{O}(3)-\mathrm{N}$ & $1.242(3)$ & $\mathrm{O}(2)-\mathrm{N}$ & $1.257(3)$ \\
\hline$N(1)-A g-N(3)$ & $162.7(8)$ & & \\
\hline $\mathrm{Ag}-\mathrm{N}(1)-\mathrm{C}(1)$ & 110.3 & $A g-N(1)-C(15)^{i}$ & $134.0(2)$ \\
\hline $\mathrm{C}(1)-\mathrm{N}(1)-\mathrm{C}(15)^{i}$ & $115.6(2)$ & $\mathrm{C}(3)-\mathrm{N}(2)-\mathrm{C}(4)$ & $110.0(2)$ \\
\hline$C(3)-N(2)-C(5)$ & $109.3(2)$ & $C(4)-N(2)-C(5)$ & $110.4(2)$ \\
\hline$A g-N(3)-C(7)$ & $109.1(2)$ & $\mathrm{Ag}-\mathrm{N}(3)-\mathrm{C}(8)$ & $134.4(2)$ \\
\hline$C(7)-N(3)-C(8)$ & $116.1(2)$ & $\mathrm{N}(1)-\mathrm{C}(1)-\mathrm{C}(2)$ & $112.1(2)$ \\
\hline$C(1)-C(2)-C(3)$ & $115.8(2)$ & $N(2)-C(3)-C(2)$ & $113.5(2)$ \\
\hline$N(2)-C(5)-C(6)$ & $113.1(2)$ & $C(5)-C(6)-C(7)$ & $115.8(3)$ \\
\hline$N(3)-C(7)-C(6)$ & $112.3(2)$ & $N(3)-C(8)-C(9)$ & $126.0(2)$ \\
\hline$C(8)-C(9)-C(10)$ & $116.9(2)$ & $C(8)-C(9)-C(14)$ & $124.1(2)$ \\
\hline$C(10)-C(9)-C(14)$ & $119.0(2)$ & $C(9)-C(10)-C(11)$ & $120.7(2)$ \\
\hline$C(10)-C(11)-C(12)$ & $120.1(2)$ & $C(11)-C(12)-C(13)$ & $118.8(2)$ \\
\hline$C(11)-C(12)-C(15)$ & $117.1(2)$ & $C(13)-C(12)-C(15)$ & $124.0(2)$ \\
\hline$C(12)-C(13)-C(14)$ & $121.1(2)$ & $C(9)-C(14)-C(13)$ & $120.2(2)$ \\
\hline$C(12)-C(15)-N(1)^{i}$ & $125.2(2)$ & $\mathrm{O}(1)-\mathrm{N}-\mathrm{O}(2)$ & $119.3(3)$ \\
\hline $\mathrm{O}(1)-\mathrm{N}-\mathrm{O}(3)$ & $120.5(3)$ & $\mathrm{O}(2)-\mathrm{N}-\mathrm{O}(3)$ & $120.1(3)$ \\
\hline
\end{tabular}

Symmetry code: ${ }^{i} 1-x,-y,-z$.

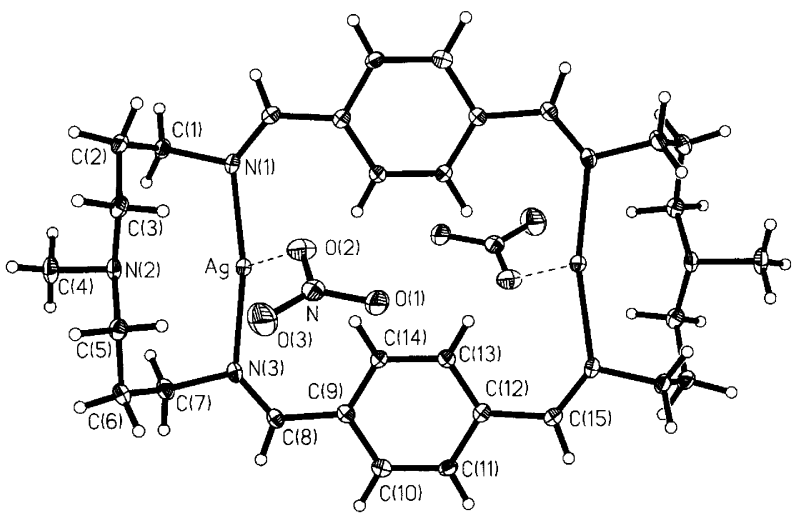

Fig. 3. The structural arrangement in $\left[\mathrm{Ag}_{2} \mathrm{~L}^{1}\right]\left(\mathrm{NO}_{3}\right)_{2}$ together with atomic numbering scheme. The interaction between silver ions and the closest nitrate oxygen atom is represented by the dashed lines.

orientations of the xylyl groups in these two complexes is presented in Fig. 4.

Copper complexes. The reaction of the reduced macrocycle $\mathrm{L}^{2}$ with copper chloride in the absence and presence of $\mathrm{PF}_{6}{ }^{-}$in methanolic solution gave the turquoisecoloured compounds $\left[\mathrm{Cu}_{2} \mathrm{Cl}_{2} \mathrm{~L}^{2}\right] \mathrm{Cl}_{2} \cdot \mathrm{CH}_{3} \mathrm{OH}$ and $\left[\mathrm{Cu}_{2} \mathrm{Cl}_{2} \mathrm{~L}^{2}\right]\left(\mathrm{PF}_{6}\right)_{2}$, respectively. Comparison of IR, UV-Vis, ESR and mass spectra indicates the cations in each of these salts are identical in solution. The blue compound $\left[\mathrm{Cu}_{2}\left(\mathrm{CH}_{3} \mathrm{CO}_{2}\right)_{2} \mathrm{~L}^{2}\right]\left(\mathrm{PF}_{6}\right)_{2} \cdot 4 \mathrm{H}_{2} \mathrm{O}$ was obtained from the reaction of $\mathrm{L}^{2}$ with copper acetate in methanol. The X-ray crystal structure of the related non- 


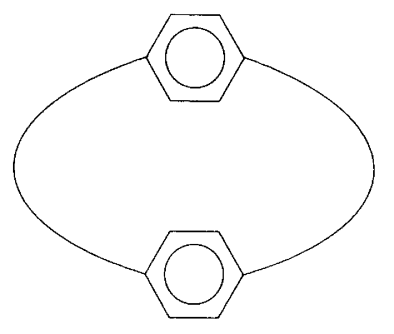

(a)

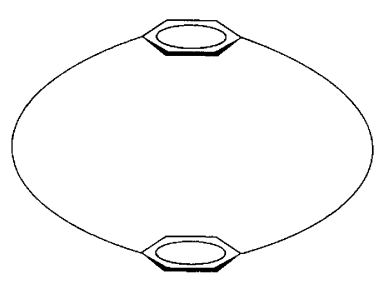

(b)
Fig. 4. Schematic representations of the orientations of the two p-xylyl groups in (a) $\left[\mathrm{Ag}_{2} \mathrm{~L}^{1}\right]\left(\mathrm{NO}_{3}\right)_{2}$ and (b) $\left[\mathrm{Cu}_{2}\left(\mathrm{CH}_{3} \mathrm{CO}_{2}\right)_{2} \mathrm{~L}^{3}\right]\left(\mathrm{ClO}_{4}\right)_{2} \cdot{ }^{13}$

methylated complex $\left[\mathrm{Cu}_{2}\left(\mathrm{CH}_{3} \mathrm{CO}_{2}\right)_{2} \mathrm{~L}^{3}\right]\left(\mathrm{ClO}_{4}\right)_{2}$ shows that each acetate group was bound to one copper atom in a bidentate fashion. ${ }^{13}$ Since the IR spectra of $\left[\mathrm{Cu}_{2}\left(\mathrm{CH}_{3} \mathrm{CO}_{2}\right)_{2} \mathrm{~L}^{2}\right]\left(\mathrm{PF}_{6}\right)_{2} \cdot 4 \mathrm{H}_{2} \mathrm{O}$ and $\left[\mathrm{Cu}_{2}\left(\mathrm{CH}_{3} \mathrm{CO}_{2}\right)_{2} \mathrm{~L}^{3}\right]-$ $\left(\mathrm{PF}_{6}\right)_{2}$ are identical, apart from the expected differences due to different counter-anions and the methyl groups, we assume a similar bidentate acetate coordination with the acetate bands at $v_{\text {OCo }}$ (asym), $1567 \mathrm{~cm}^{-1}$, and $v_{\text {OCo }}(\mathrm{sym}), 1429 \mathrm{~cm}^{-1}$, in the IR spectrum.

The ESR spectra of the copper(II) complexes reveal that there is no significant exchange coupling between the $\mathrm{d}^{9}$ copper ions. The absence of magnetic interaction is not surprising in view of the lack of suitable exchange pathways, ${ }^{14}$ since the spectroscopic evidence suggests that neither the chloride ions, acetate ions or possible coordinated solvent act as bridging ligands between the two encapsulated copper ions; the only bridging element between the copper ions is the macrocycle framework which is not expected to provide a magnetic exchange pathway. The ESR spectra of solid samples of $\left[\mathrm{Cu}_{2} \mathrm{Cl}_{2} \mathrm{~L}^{2}\right] \mathrm{Cl}_{2} \cdot \mathrm{CH}_{3} \mathrm{OH}$ and $\left[\mathrm{Cu}_{2} \mathrm{Cl}_{2} \mathrm{~L}^{2}\right]\left(\mathrm{PF}_{6}\right)_{2}$ are different; $\left[\mathrm{Cu}_{2} \mathrm{Cl}_{2} \mathrm{~L}^{2}\right] \mathrm{Cl}_{2} \cdot \mathrm{CH}_{3} \mathrm{OH}$ affords an axial signal with $g_{\perp}=2.208$ and $g_{\|}=2.078$, while $\left[\mathrm{Cu}_{2} \mathrm{Cl}_{2} \mathrm{~L}^{2}\right]\left(\mathrm{PF}_{6}\right)_{2}$ shows a rhombic signal with $g_{x}=2.046, g_{y}=2.143$ and $g_{z}=2.179$. The observation of a difference in the ESR spectra of these compounds which we propose contain identical cations is likely to be related to their solid state structure. An interaction of the chloride counter-anions with the copper ions may be present in the solid state, for example, by $\mu$-chloro bridging between adjacent dinuclear cations and thus giving rise to pseudo-fivecoordinated copper ions. The possibility of counter-anion interaction with the copper centres is removed in the case of the hexafluorophosphate complex. The actetate complex $\left[\mathrm{Cu}_{2}\left(\mathrm{CH}_{3} \mathrm{CO}_{2}\right)_{2} \mathrm{~L}^{2}\right]\left(\mathrm{PF}_{6}\right)_{2} \cdot 4 \mathrm{H}_{2} \mathrm{O}$ gives rise to an axial signal with $g_{\perp}=2.090$ and $g_{\|}=2.191$.

\section{Concluding remarks}

The silver templated reaction reported here affords a simple one-pot preparation of the tetra Schiff base macrocyle $\mathrm{L}^{1}$. The isolation of the free $\mathrm{L}^{1}$ by iodide assisted removal of silver represents a new development in the chemistry of Schiff base macrocycles and offers the possibility of preparing other metal complexes of $\mathrm{L}^{1}$. We have carried out a preliminary investigation into the copper( $\mathrm{I}$ ) coordination chemistry of $\mathrm{L}^{1}$; however, as yet we have not characterized any products; the reaction of $\left[\mathrm{Cu}\left(\mathrm{CH}_{3} \mathrm{CN}\right)_{4}\right]\left(\mathrm{BF}_{4}\right)$ with $\mathrm{L}^{1}$ in an inert atmosphere results in formation of yellow solutions from which we are unable to isolate solid products. On exposure to air these solutions turn green within seconds, indicating oxidation of the copper(I) to copper(II). Elaboration of this chemistry will be the subject of ongoing work. Apart from pursuing the study of copper(I) complexes of $\mathrm{L}^{1}$ and their possible reactivity towards molecular oxygen, these macrocyles offer the possibility of further modification. Future work will involve the derivatization of the secondary nitrogen atoms of $\mathrm{L}^{2}$ with metal binding groups to give bis-pentadentate macrocylic ligands for the study of dinuclear complexes of transition metal ions with a preference for higher coordination numbers.

Acknowledgements. We thank ERASMUS student Válerie Gandubert for help in the initial stages of the synthetic work. Support from the Danish Natural Science Council (grant no. 9503162 to C.J.M.) is acknowledged. Jens Z. Pedersen is thanked for recording the ESR spectra.

\section{References}

1. L. F. Lindoy, The Chemistry of Macrocylic Ligand Complexes. Cambridge University Press, Cambridge 1989. See, for example: (a) Harding, C., McDowell, D., Nelson, J., Raghunathan, S., Stevenson, C., Drew, M. G. B. and Yates, P. C. J. Chem. Soc., Dalton Trans. (1990) 2524; (b) Abid, K. K., Fenton, D. E., Casellato, U., Vigato, P. A. and Graziani, R. J. Chem. Soc., Dalton Trans. (1984) 351; (c) Hoskins, B. F., Robson, R. and Smith, P. J. Chem. Soc., Chem Commun. (1990) 488; (d) Tandon, S. S., Thompson, L. K. and Brisdon, J. N. Inorg. Chem. 34 (1995) 5507; (e) Brooker, S., McKee, V., Shepard, W. B. and Pannell, L. K. J. Chem. Soc., Dalton Trans. (1987) 2555; (f) Nanda, K. K., Venkatsubramanian, K., Majumdar, D. and Nag, K. Inorg. Chem. 33 (1994) 1581; (g) Adams, H., Bailey, N. A., Bertrand, P., Collinson, S. R., Fenton, D. E. and Kitchen, S. J. Inorg. Chim. Acta, 250 (1996) 139; (h) Collinson, R. and Fenton, D. E. Coord. Chem. Rev. 148 (1996) 19; (i) Salata, C. A., Youinou, M.-T. and Burrows, C. J. J. Am. Chem. Soc. 111 (1989) 9278. (j) Fenton, D. E., Matthews, R. W., McPartlin, M., Murphy, B. P., Scowen I. J. and Tasker, P. A. J. Chem. Soc., Dalton Trans. 16 (1996) 3421.

2. (a) Drew, M. G. B., Harding, C. J., Howarth, O. W., Lu, Q., Marrs, D. J., Morgan, G. G., McKee, V. and Nelson, J. J. Chem. Soc., Dalton Trans. (1996) 3021; (b) Drew, M. G. B., Yates, P. C., Esho, F. S., TrochaGrimshaw, J., Lavary, A., McKillop, K. P. Nelson S. M. and Nelson, J., J. Chem. Soc., Dalton Trans. (1988) 2995; (c) Bailey, N. A., Fenton, D. E., Moody, R., Rodriquez de Barbarin, C. O., Sciambarella, I. N., Latour, J.-M., Limosin, D. and McKee, V. J. Chem. Soc., Dalton Trans. (1987) 2519.

3. (a) Nelson, S. M., Esho, F., Lavery, A. and Drew, M. G. B. J. Am. Chem. Soc. 105 (1983) 5693; (b) Sharma, P. and Vigee, G. S. Inorg. Chim. Acta 88 (1984) 29; (c) Moore, K. and Vigee, G. S. Inorg. Chim. Acta 66 (1982) 125; (d) Curtis, N. J., Hagen K. S. and Sargeson, A. M. J. Chem. Soc., 
Chem. Commun. (1984) 1571; (e) Agnus, Y., Gisselbrecht, J. P., Louis, R. and Metz, B. J. Am. Chem. Soc. 111 (1989) 1494; (f) Drew, M. G. B., Yates, P. C., TrochaGrimshaw, J., McKillop K. P. and Nelson, S. M. J. Chem. Soc., Chem Commun. (1985) 262.

4. Menif, N., Martell, A. E., Squattrito, P. J. and Clearfield, A. Inorg. Chem. 29 (1990) 4723.

5. Pietraszkiewicz, M. and Gasiorowski, R. Chem. Ber. 123 (1990) 405.

6. Cosier, J. and Glazer, A. M. J. Appl. Crystallogr. 19 (1986) 105.

7. Nielsen, K. To be published.

8. Sheldrick, G. M. Acta Crystallogr., Sect. A 46 (1990) 467.

9. Sheldrick, G. M. SHELXL93. Program for Crystal Structure Refinement. University of Göttingen, Germany (1993).
10. International Tables for X-Ray Crystallography. Kynoch Press, Birmingham 1974, Vol. IV (Present distributor: Kluwer Academic Publishers, Dordrecht).

11. Sheldrick, G. M. SHELXTL95. Siemens Analytical X-ray Instruments Inc., Madison, WI 1995.

12. Spek, A. L. Acta Crystallogr., Sect. A 46 (1990) C-34.

13. McKenzie, C. J., Toftlund, H., Pietraszkiewics, M., Stojek, Zb. and Slowinski, K. Inorg. Chim. Acta 210 (1993) 143.

14. D. N. Hendrickson. In Willett, R. D., Gatteschi, D. and Hahn, O., Eds., Magneto-Structural Correlations in Exchange Coupled Systems, Reidel, Dortrecht 1985, p. 523.

Received August 14, 1997. 